\title{
FOREIGN DIRECT INVES TMENT IN CHINA: Effects on Growth and Economic Performance
}

\author{
Edward M. Graham \\ Senior Fellow \\ Institute for International Economics \\ Erika Wada \\ Research Associate \\ Institute for International Economics
}

To appear in Achieving High Growth:

Experience of Transitional Economies in East Asia,

Peter Drysdale, editor, Oxford University Press, forthcoming 2001.

The authors wish to thank Dr. Chi Zhang (Stanford University), Dr. Jun Ma (Deutschebank), Professor Lori Kletzer (University of California and IIE), and Dr. Aasim M. Husain (International Monetary Fund) for valuable input and comments on earlier drafts of this paper. 


\section{INTRODUCTION}

By almost all accounts, foreign direct investment (FDI) in China has been one of the major success stories of the past 10 years. Starting from a base of less than $\$ 19$ billion in 1990, the stock of FDI in China rose to over $\$ 300$ billion at the end of 1999 . Ranked by the stock of inward FDI, China thus has become the leader among all developing nations and second among the APEC nations (only the United States holds a larger stock of inward FDI). ${ }^{1}$ China's FDI consists largely of greenfield investment, while inward FDI in the United States by contrast has been generated more by takeover of existing enterprises than by new establishment, a point developed later in this paper. The majority of FDI in China has originated from elsewhere in developing Asia (i.e., not including Japan). Hong Kong, now a largely self-governing "special autonomous region" of China itself, has been the largest source of record. The dominance of Hong Kong, however, is somewhat illusory in that much FDI nominally from Hong Kong in reality is from elsewhere. Some of what is listed as Hong Kong-source FDI in China is, in fact, investment by domestic Chinese that is "round-tripped" through Hong Kong (see footnote 2). Other FDI in China listed as Hong Kong in origin is in reality from various western nations and Taiwan that is placed into China via Hong Kong intermediaries. Alas, no published records exist to indicate exactly how much FDI in China that is nominally from Hong Kong is in fact attributable to other nations.

According to official sources, in the period 1992-96, FDI from developing Asian nations dominated total FDI flows into China, but since 1996 a growing portion of these flows has come from other sources (i.e., Europe, North America, and Japan). This latter FDI generally has been of a different character than FDI from developing Asian nations. While the latter has been concentrated in exportprocessing activities in sectors in which China has revealed comparative advantage, much of the former has been directed more toward the domestic market in sectors in which China has no revealed comparative advantage. Thus one consequence of a rising percentage of FDI from Japan, Europe, and North America has been that overall the activities of foreign-invested enterprises ${ }^{2}$ in China have become somewhat more focused on the domestic market, and less on export markets, in the la te 1990s relative to the mid-1990s. The consequences are discussed in more detail later in this paper.

\footnotetext{
${ }^{1}$ However, some of the stock is known to be the result of "round tripping", i.e., Chinese domestic savings intermediated as direct investment in order for the investment to receive incentives available to foreign investors that are not available to domestic investors. Most of this investment is recorded as being from Hong Kong. The exact extent of round tripping is not known, and it is not discussed further in this paper.

2 "Foreign invested enterprises" is a somewhat euphemistic term used in China to denote local affiliates of foreignowned firms. Many of these local affiliates are joint ventures with Chinese enterprises and, indeed, until 1992 almost all foreign direct investment in China was in the form of joint ventures. The term "foreign-invested" thus seems to have been employed to reassure anyone who might care that these ventures were really domestic firms with
} 
These changes notwithstanding, there is little doubt that FDI has contributed significantly to Chinese economic development: much and perhaps most of the growth of China's exports can be attributed to foreign-invested enterprises and per capita income growth in those regions of China where FDI is concentrated has been significantly higher than in other regions. Specifics of some of the major empirical fin dings are discussed in the following two sections of this paper. Section 2 reviews some findings published elsewhere, and section 3 presents some additional findings by the authors.

However, the story of FDI in China is not quite as rosy as these summary sentences suggest. By all accounts, the policy environment for foreign direct investors in China is difficult, and much anecdotal evidence suggests that some of these investors are becoming discouraged by this environment while other potential investors have been deterred by it. ${ }^{3}$ This discouragement seems to be indicated by the fact that the flow of FDI decelerated in the late 1990s. However, data for the most recent years are almost always subject to significant future revisions, so it is premature to read too much into the 1999 or even the 1998 data. Keeping this in mind, the number of investments in 1998 declined relative to 1997 by a larger percentage than FDI flow, indicating that the average size of the individual investment undertaking rose somewhat. This rise in average size of investment was driven by the changing source of the investment; Japanese and western direct investors tend to make larger investments than investors from developing Asia. Also, it should be kept in mind investment from developing Asian sources was negatively affected by the Asian financial crisis of 1997-98 and that the impact of the crisis was felt most heavily in 1998. Anecdotal evidence suggests that it is western and Japanese multinationals that are most discouraged by the current policy environment in China. Thus, if the Chinese are counting on FDI from the west and Japan to continue to make up for declining FDI from non-Japanese Asian sources, there might be cause for concern.

In this light, it is slightly ominous that US and Japanese data suggest that FDI from these countries to China has dropped substantially in 1999 over levels of 1998 (see tables 1 and 2). In the case of Japan, FDI flows to China in fact have dropped steadily since 1995, both in terms of absolute amount and the percent of Japan's total FDI outflow. In the case of the United States, starting from a lower base than in the case of Japan, FDI flows to China increased from 1995 to 1998 both in terms of absolute amount and percent of total US FDI outflow. However, 1999 saw a reversal of both trends. Again, it is simply way too soon to say with any certainty whether these drops signal the beginning of a trend toward decreased foreign investment from the United States or Japan into China but, nonetheless, the simple fact that there were declines is not wholly auspicious.

foreign participation. Since 1992, a growing percentage of local affiliates of foreign firms are majority or wholly owned by the foreign investors, but the term "foreign-invested" continues to apply even to these. 
Table 1 Japanese direct investment flow into China, 1996-99

(\$ US billions or percent)

\begin{tabular}{lcccc}
\hline & $\mathbf{1 9 9 6}$ & $\mathbf{1 9 9 7}$ & $\mathbf{1 9 9 8}$ & $\mathbf{1 9 9 9}$ \\
\hline Flow to China & 2.51 & 1.99 & 1.07 & 0.75 \\
$\begin{array}{l}\text { Percent change from } \\
\text { previous year }\end{array}$ & -44 & -21 & -46 & -30 \\
$\begin{array}{l}\text { Flow to all nations } \\
\text { Flow to China as }\end{array}$ & 48.02 & 53.97 & 40.75 & 66.69 \\
$\begin{array}{l}\text { percent of flow to } \\
\text { all nations }\end{array}$ & 5.2 & 3.7 & 2.6 & 1.1 \\
\hline
\end{tabular}

Source: Japan External Trade Organization (JETRO).

Table 2 US stock and flow of direct investment to China, 1996-99

(\$ US billions or percent)

\begin{tabular}{|c|c|c|c|c|}
\hline & 1996 & 1997 & 1998 & 1999 \\
\hline Flow to China & 0.93 & 1.25 & 1.67 & 1.21 \\
\hline $\begin{array}{l}\text { Percent change of } \\
\text { flow from previous } \\
\text { year }\end{array}$ & 257 & 34 & 34 & -38 \\
\hline Flow to all nations & 84.43 & 95.77 & 134.08 & 138.51 \\
\hline $\begin{array}{l}\text { Flow to China as } \\
\text { percent of flow to all } \\
\text { nations }\end{array}$ & 1.1 & 1.3 & 1.3 & 0.9 \\
\hline
\end{tabular}

Source: US Department of Commerce, Bureau of Economic Analysis (BEA).

${ }^{3}$ On this, see the many case examples discussed in Rosen (1999). 
The data as indicated in table 2 are, as noted, from Japanese and US sources. In fact, Chinese sources show significantly larger flows and stocks of FDI into China from the United States than do US sources and somewhat larger flows and stocks from Japan. To the best of the authors' knowledge, the reasons for the discrepancies have not been wholly sorted out but one factor does seem to be that some US and Japanese firms place their investment on the mainland via subsidiaries in Hong Kong, so that this investment shows up in the home country data as direct investment in Hong Kong. Thus, table 3 below indicates flows of Japanese and US direct investment in Hong Kong (1996-99), using home country data. The US data indicate much volatility, with major increases in flows over the previous year being recorded in 1996 and 1997, a major drop in 1998, and a recovery in 1999. The Japanese data show, as for the mainland, a significant drop in FDI flows since 1996-98, but some recovery in 1999.

Table 3 US direct investment flows to Hong Kong, 1996-99 (\$US billions or percent)

\begin{tabular}{|c|c|c|c|c|}
\hline & 1996 & 1997 & 1998 & 1999 \\
\hline $\begin{array}{l}\text { Japanese FDI } \\
\text { flow to Hong } \\
\text { Kong }\end{array}$ & 1.49 & .70 & .60 & .97 \\
\hline $\begin{array}{l}\text { Percent change } \\
\text { from previous } \\
\text { year }\end{array}$ & 32 & -53 & -13 & 61 \\
\hline $\begin{array}{l}\text { US FDI flow to } \\
\text { Hong Kong }\end{array}$ & 1.69 & 3.76 & 1.83 & 2.60 \\
\hline $\begin{array}{l}\text { Percent change } \\
\text { from previous } \\
\text { year }\end{array}$ & 168 & 124 & -105 & 42 \\
\hline
\end{tabular}

Source: US Department of Commerce, Bureau of Economic Analysis (BEA). 
In sum, there is some evidence that the rate of flow of FDI into China during the late 1990s experienced some slowing down over the levels of the middle 1990s but this evidence is far from conclusive. What is clear is that FDI flows into China have not continued to grow at the rates that were evident in recent years. Further, the slowdown (or lack of growth) is unlikely to be the result of saturation effects. For example, in spite of the large stock of FDI that has entered China to date, on a per capita basis this stock is in fact not great when compared with other Asian nations, for example, the Chinese stock per capita is about $\$ 160$, in contrast to $\$ 320$ in Thailand and more than $\$ 2,000$ in Malaysia (Lemoine 2000). Also, the role of FDI in the Chinese economy by several measures (e.g., value added by foreign invested enterprises as a percent of manufacturing value added in the domestic economy) is not high relative to this role in other Asian economies (Lemoine 2000 op. cit.). Further, the sectoral and locational distribution of this investment is very uneven. For instance, the majority of FDI in China is located in four coastal provinces (Guangdong, Jiangsu, Fujian, and Shanghai, in descending order) and most of the rest of this FDI is located in other coastal provinces. Of the residual, the majority is located in provinces immediately adjacent to the coastal provinces. Thus, vast areas of China, including ones where much state-owned industry is located, have not been touched by FDI. In spite of the large flows that have come to China since 1990, there would appear to be ample capacity for China to absorb much more.

Against these figures, it is also noteworthy that FDI approvals by Chinese authorities have risen in 2000 and 2001 over approvals in 1998 and 1999, suggesting that the trends reported above, if indeed the data do suggest trends, could be reversed. One interpretation of the rise of approvals is that foreign investors have been registering intent to invest in China in anticipation of reforms that are likely to accompany Chinese entry into the World Trade Organization. Whether or not this impending entry will actually result in realization of the investment is a matter that largely remains to be seen.

Even if investors are becoming discouraged by the policy environment currently prevailing in China, the emergence of China as a major host nation to FDI has nonetheless been driven by positive changes in Chinese policy over the last quarter century or so. From 1949 until 1979, China had been closed entirely to FDI but as part of a series of reforms a partial opening was implemented in 1979 such that highly limited access to the Chinese market was granted to foreign investors (Rosen 1999 op. cit.). At that time China sought access to foreign capital and technology but also sought to avoid creating any competition whatsoever for domestic state-owned enterprises from foreign owned firms. The result was that only a small amount of FDI entered China over the next 12 years and this was concentrated in sectors in which either domestic Chinese firms did not participate (hotel development, tourism) or ones where China urgently needed access to foreign technology (oil field exploration and development). Beginning in 1992, however, further reforms were taken that led to a surge in FDI. Some of the early post-1992 FDI 
was concentrated in nontraded goods (e.g., commercial real estate development) but a priority of China was development of new export industries, and by 1994 about 60 percent of FDI was flowing into industrial sector activities that were highly export-intensive. As noted above, in more recent years, an increasing percentage of output of foreign-invested enterprises has served the domestic rather than the export market but, even so, FDI in China remains concentrated in export-intensive activities. Indeed, some analysts figure that almost all of the growth of Chinese exports since 1992 can be directly or indirectly attributed to foreign-invested enterprises (Wei 1995 and 1996, Lemoine 2000, op. cit.).

This is not necessarily however an entirely unalloyed benefit. As developed further in the next section, foreign-invested enterprises largely engaged in export processing are not well integrated into the mainstream Chinese economy. Rather, these operations are used to perform labor-intensive operations on imported goods for re-export. (Or, at least, so goes the usual story. As is developed later, this story itself might not be wholly correct.)

Even after the 1992 reforms, however, foreign direct in vestment in China remains very controlled by state policy and, indeed, significant changes in this policy would seem to be indicated by China's admission to the WTO. Currently, the central government of China, as well as provincial governments, do regulate entry of FDI closely or at least attempt to do so. Entry of foreign firms is often conditioned on the achievement of industrial policy goals as laid out by the state. Foreign firms are most welcome when these goals cannot be fulfilled by domestic firms. The entry of a foreign firm can be subject to numerous conditions, for example, such performance requirements as having to use local suppliers, often designated by the government, or locating in certain areas, or setting up the local operation as a joint venture. Also, much the same thing can be said about this policy today as was said a few paragraphs back about past policy, notably that China seeks access to foreign capital and technology but often still seeks to avoid or, barring complete avoidance, at le ast to regulate competition between domestic enterprises and foreigninvested ones. Thus, while the aversion to competition has softened in recent years, it has certainly not entirely gone away.

Arguably, one consequence is that China has to some extent foregone one of the major sources of benefit of FDI, notably the dynamic gains that come from greater competition. Ironically, to the extent to which this has happened, China also probably has foregone much, albeit certainly not all, of the benefit that comes from access to foreign technology. This issue is further discussed in the next section of this paper. Another possible consequence is even more ironic: by sheltering domestic enterprises, and particularly the state-owned sector, from foreign competition, ${ }^{4}$ China almost surely has reinforced the

\footnotetext{
${ }^{4}$ The state-owned sector in China, to be sure, is shrinking in terms of the percent of output originating in this sector. But, by most accounts, this is only a relative shrinkage; output in this sector is stagnant, but growing in the private
} 
locational advantages with respect to FDI already held by the coastal provinces. This is indeed ironic because one lamentation in China about foreign investment is that the benefits have largely accrued to the coastal provinces, with inland areas getting left behind. But the economies of the inland provinces tend to be more dominated by state-owned enterprises than those of the coastal provinces, and measures taken to shelter state-owned enterprises from competition by foreigners (and effectively to block foreign takeover of these) works to the locational disadvantage of the inland provinces. In the final section of this paper, we argue that the most effective means to draw FDI to inland areas would indeed be to privatize stateowned enterprises and to allow foreign ownership of these. Again, whether this will happen in the postWTO entry era remains to be seen.

The remainder of this paper is divided into three sections. The next section (section 2) examines what has been the record of FDI to date in China, focusing on a number of recently published studies. What is revealed, as has already been suggested, is that the benefits have been very great indeed. However, as also has been suggested, the distribution of the benefits has been very uneven and there certainly remain potential gains that have not been realized. Section 3 augments these published studies with some findings of our own, ones that are roughly consistent with the already-published findings. Section 4 presents some concluding remarks.

\section{EMPIRICAL EVIDENCE OF GAINS TO CHINA FROM FOREIGN DIRECT INVESTMENT: GROWTH AND EXPORTS}

As just indicated, FDI in China has stimulated much growth in income that would almost surely not have been realized in the absence of this investment, as is demonstrated in two very recent but quite different working papers (Lemoine 2000, op. cit., and DayatGulati and Husain 2000, henceforth D-G\&H). The former of these is largely descriptive but provides both substantial scope and depth of detail, while the latter is largely econometric. Together, they demonstrate what by now is a commonly told story about FDI in China: FDI has significantly benefited the coastal regions while most of the rest of China has benefited much less. Together, the two studies also provide evidence that this outcome is not wholly the consequence of natural locational advantages held by the coastal provinces but, rather, is in part the consequence of Chinese policy.

The core of D-G\&H is use of what they call a Mankiw, Romer, and Weil version of the Solow growth model to test for convergence of income growth to a steady state across provinces of China. ${ }^{5}$ To

domestically owned and foreign-owned sectors. Many analysts believe that absolute shrinkage of state-owned enterprises in China must be accomplished.

${ }^{5}$ Mankiw, Romer, and Weil (1992). In their empirical tests, D-G\&H aggregate the provinces into six regions, north, northeast, coastal, south, southeast, and west. In this aggregation, the vast majority of FDI is in the coastal region, with the remainder in the north and northeastern regions. 
explore the D-G\&H results, including our criticism of these results, some understanding of this model is necessary. Thus, for the reader who is not familiar with the model, a brief explanation is provided in an appendix to this chapter.

In fact, D-G\&H use a truncated version of the Mankiw, Romer, and Weil version of the Solow model as described in the appendix. Specifically, D-G\&H use the following specification:

$$
\ln y_{i t}-\ln y_{i 0}=C-\left(1-e^{-\lambda t}\right) y_{i 0}+x_{i t}+\varepsilon_{i t}
$$

where the $\mathrm{i}$ indexes province, $\mathrm{C}$ is "a constant term across all provinces", $\mathrm{x}_{\mathrm{it}}$ is a vector of "other explanatory variables", and $\varepsilon_{\mathrm{it}}$ is an error term. As developed in the appendix, in the full Mankiw, Romer, and Weil model, $\mathrm{x}_{\mathrm{it}}$ would include terms involving population growth, savings rate, depreciation rate, human capital investment rate, etc. However, D-G\&H omit most of these variables for the simple reason that necessary data are not available. However, arguably the most important variable, fixed investment to provincial GDP, is included. But also, D-G\&H throw in some other variables that do not figure in the Mankiw et al. version, notably share of state-owned enterprises in industrial output, share of FDI in provincial GDP, ratio of public revenue to public expenditure, and ratio of bank loans to deposits. Of critical importance is inclusion of FDI; the main goal is to test whether FDI has contributed sig nificantly to the growth of China by province and, in particular, whether the higher per capita growth in the coastal provinces can correctly be attributed to the high rates of foreign investment there. According to them, the likely answer is "yes". As they note, "higher FDI flows could imply more openness, and thereby a higher rate of convergence, or access to different technology, implying convergence to a higher steady state, at least in the short run". However, to test this, they must also look at other explanations for the growth differentials, thus introduction of other potential explanatory variables.

Their main results are (1) per capita income convergence rates among provinces were not constant over time (or, more precisely, the hypothesis that these rates were constant over time can be rejected); (2) the hypothesis of "unconditional convergence" (that per capita incomes were converging to the same level in all provinces) can be rejected ${ }^{6}$; and (3) FDI, as expected, both affects significantly and positively the level of per capita income to which provinces are converging and the rate of income growth. Regarding the third result, as would be expected if there were unconditional convergence, per capita income in the poorest provinces of China grew faster than in the richer provinces during the early 1980s, when FDI was not nearly as large a factor in China's development as it is today. But this was

\footnotetext{
${ }^{6}$ To restate this and hopefully to clarify it, the rates of per capita income growth to which the provinces of China are converging differ among provinces.
} 
reversed during the 1990s when FDI poured into the coastal areas (as also happened in the northern and northeastern regions when FDI began to flow there in the late 1990s).

D-G\&H also find that the loan-deposit ratio by province has a negative impact on growth, especially in the time period 1988-97. They interpret this, following Lardy (1998), to be the result of "policy loans" to state-owned enterprises, that is, state-owned banks in China are forced to lend to lossmaking state-owned firms on noncommercial terms, causing this ratio to rise in those provinces where such loss-making firms are concentrated. Thus, a high loan-to-deposit ratio would signal that the government was forcing the intermediation of savings into capital with low returns at the margin in the affected region. ${ }^{7}$ In contrast, they find that ratio of revenue to expenditure by province has little relationship with per capita income growth. Likewise, the ratio of investment to provincial GDP does not significantly affect this growth, although inclusion of the variable increases the estimated rate of variance $\lambda$ as measured by it.

Overall, the D-G\&E results show robustly that FDI in the coastal areas of China is positively associated with relatively higher rates of per capita income growth. They also show, albeit arguably less robustly, that government policy has suppressed per capita income growth in areas where state-owned enterprises are concentrated. Somewhat separately from their econometric results, D-G\&E also show that the latter provinces--those where state-owned enterprises are most concentrated-are not the provinces where FDI is concentrated. A reasonable conclusion would be that for some reason foreign investors shy away-or are discouraged-from areas where state-owned enterprises are prevalent. ${ }^{8}$

One can quibble, however, both with the D-G\&H model and with the authors' interpretation of their results. The most serious flaw of their model is omission of important variables that figure in the Mankiw, Romer, and Weil version of the Solow model, without which it is not clear that the D-G\&H version is on particularly solid theoretical footing. Importantly, exclusion of these variables prevents them from performing the sort of "consistency test" that caused Mankiw et al. to reject the original Solow model as an explanator of differences in real per capita growth rates among nations (this test, as developed in the appendix, was to determine whether the model yielded a plausible income share of capital $\alpha$ ). Also, we find ourselves not wholly convinced by the D-G\&H's argument that the relatively

\footnotetext{
${ }^{7}$ Indeed, savings are either used to finance output that is sold at a loss or is retained as inventory; in either case, the return at the margin is zero or negative.

${ }^{8}$ This, however, by itself does not prove that government policies discourage FDI from locating in proximity to state-owned enterprises either deliberately or even inadvertently. It could be that coastal areas possess locational advantages for foreign investors but not for state-owned enterprises. Conversely (and as they seem to be true as artifacts of policy in the early years of the People's Republic of China), state-owned enterprises might have been forced to locate operations in areas that were not optimal from a commercial perspective. Chairman Mao, for example, sought to disperse Chinese industry and to locate it in areas away from the coast for reasons of national defense and as a way of rewarding those regions of China that had most strongly backed the Communist revolution.
} 
faster rates of per capita income growth in the coastal provinces during the 1990s was the result of higher capital mobility in these provinces as revealed (or perhaps induced) by FDI inflows.

A more reasonable interpretation is that total factor productivity (TFP) growth accelerated in these provinces as a result of technology transfer resulting from this inflow. Indeed, this story would be more consistent with the finding of Lemoine (described in detail below) that FDI from non-Japanese Asian sources largely flowed into noncapitarintensive activities in which China had strong revealed comparative advantage, albeit that later, FDI from Europe, Japan, and North America often tended to be in more capital intensive activities. D-G\&H of course do indicate that TFP increases resulting from technology transfer via FDI could be driving growth, but their methodology does not test directly for this. For this reason, we have performed some simple tests to determine whether in fact the TFP growth rates do differ across Chinese provinces and, also, whether these rates changed in the relevant provinces following the rapid build-up of FDI in China after 1991. (Our results are presented in the next section). We find that our own results largely corroborate that TFP increases do account for the relatively better performance of the coastal provinces during the 1990s.

Importantly, the findings that those provinces with high rates of FDI inflow did achieve significantly higher per capita growth rates and that this higher performance can be causally linked to FDI suggest that, contrary to some claims (see below), FDI has done more than simply create low-wage employment in China.

It is useful to juxtapose the econometrically derived results of $\mathrm{D}-\mathrm{G} \& \mathrm{H}$ with the more descriptive empirical findings of Lemoine. As already suggested, Lemoine finds that almost all of China's export growth during the 1990s can be attributed to foreign-invested enterprises, but that most of this growth can be attributed to non-Japanese Asian source FDI that flowed into labor-intensive export processing activities. These activities have been concentrated in a relatively small set of industrial subsectors, for example, electrical and electronic goods, apparel, footwear, toys, leather goods, instruments, and furniture. Lemoine argues that most of these activities consist of labor-intensive operations to transform imported intermediate goods into finished or semi-finished goods, which are then re-exported (hence the term "export processing"). Citing earlier studies, Lemoine argues that the benefits of this FDI are somewhat limited, for example, the resulting foreign-invested enterprises might create jobs but would be expected to generate little in the way of positive externalities such as technology transfer or integration of domestic Chinese enterprises into integrated global production structures. Given, however, that nonJapanese Asian FDI does (still) dominate total FDI into China, as suggested above, the D-G\&H results suggest that Lemoine might be understating the benefits of this investment. This is particularly so if one 
accepts that the source of the relatively high per capita growth rates in the coastal provinces must come from TFP increases over and above those recorded in other provinces.

Interviews conducted by one of the present authors (Graham) in Taiwan in 1996 and 1997 in fact provided anecdotal evidence that Taiwanese electronics manufacturers, for example, were not simply establishing simple labor intensive assembly operations on the Chinese mainland to take advantage of low-cost, low-skilled labor, as Lemoine implies. According to these Taiwanese investors, they were also establishing operations there that were intensive in use of human capital, if not physical capital. This of course suggests that human capital formation in the coastal provinces somehow interlinks with FDI to generate growth, a possibility alas left untouched by the D-G\&H work even if this possibility would seem to make sense in terms of the Mankiw, et al. empirical findings. ${ }^{9}$

But if there is evidence that the benefits of developing Asian source FDI into China might be greater than one would expect from simple labor-intensive export processing, Lemoine does present some evidence pointing the other way. She finds, for example, consistent with earlier findings, that foreigninvested enterprises engaged in export processing generate less local value added per unit of output than do domestically owned enterprises engaged in similar activities. This could result from the use of fewer domestically sourced inputs by the foreign invested enterprises than by their domestically owned rivals, including input of more skilled labor. It could also be the result (as some analysts indeed have suggested) of transfer pricing to minimize realized earned income in China. Of course, if the latter is true, then the finding itself is an artifact of the transfer pricing, that is, if the imported inputs and exported outputs were priced at correct values, the foreign-invested enterprises might be shown to generate as much local value added per unit of output as their domestic counterparts.

Lemoine also documents that more recent FDI into China from Europe and North America is concentrated in subsectors in which China has no revealed comparative advantage and that the output of activities created by this investment tend more to serve the local market, and less export markets, than earlier vintage non-Japanese Asian source FDI. Enterprises under European control tend in fact to be the most concentrated on the domestic market, while American-controlled enterprises fall in between nonJapanese Asian-controlled enterprises and European-controlled ones. Like Asian-controlled export processing activities, European- and American-controlled activities are concentrated in a small number of subsectors (but the two sets of subsectors are, of course, not the same). This possibly is because many of these activities were admitted into China to serve industrial policy goals.

Two interesting possibilities emerge. The first is that these operations are purely anti-trade, that is, import-substituting. In two of the sectors in which foreign-invested enterprises are heavily involved in

\footnotetext{
${ }^{9}$ To be fair to D-G\&H, however, their omission of consideration of human capital derives from data limitations.
} 
the domestic Chinese market, food processing and transport (automobiles, buses, and trucks), these enterprises in fact operate behind very high tariff walls. Long history with foreign investment activities operating behind high tariff walls to achieve import substitution does not in fact tell a wholly favorable tale about such activities. ${ }^{10}$ If the goal is to achieve a modern, competitive, technologically up-to-date local industry, the goal is rarely achieved. Rather, in the absence of real competition, foreign-controlled enterprises can be every bit as slack as domestically controlled firms operating under similar circumstances. Further, and perhaps even worse, most government measures such as local content requirements, technology transfer requirements, and the like that are meant to stimulate better performance from foreign- controlled enterprises tend to be at best ineffective and often counterproductive. ${ }^{11}$ Because the enterprise faces no competition, there is little incentive for it to use, say, its latest and best technologies. Performance requirements can create an actual disincentive, especially if the host nation cannot ensure intellectual property protection. Especially when the foreign-controlled enterprise is a joint venture or is forced to deal with local suppliers that the investor does not choose, the foreign investor might be especially reluctant to transfer any technology that is considered to be proprietary, for fear of loss of that technology.

But the second possibility is that these enterprises are on the forefront of creating new industrial capabilities in China or reinvigorating old ones. In this regard, the experience of the United States holds some lessons. ${ }^{12}$ For example, during the 1980s, US automotive manufacturers were beleaguered by foreign competition, mostly through imports, from which they sought relief. The problems of the US industry were largely self-made. Plants were inefficient by world-class standards, product quality was low, and product design and technology was behind that of major competitors from Japan and Europe. Foreseeing the possibility of a protectionist reaction to the plight of the domestic US automobile manufacturers, the three largest Japanese automobile-producing firms embarked on a program of massive direct investment in the United States. The US Government, although it had enacted de facto quotas (disguised as voluntary restraints) on imports of Japanese automobiles, refused to impose any restrictions on this direct investment, resisting even calls from protectionist members of Congress that the domestic US operations of Japanese firms be subject to local content requirements. The result that took place over the next ten years or so was a massive restructuring of the whole US sector. Domestically owned plants became more efficient, product design and quality improved, and the competitive position of the US-

\footnotetext{
${ }^{10}$ See Moran 1998, who reviews a mass of relevant literature

${ }^{11}$ Moran 1998, op. cit. Moran does find, however, that export performance requirements can be effective at fostering internationally competitive activities, for the straightforward reason that to export successfully, an enterprise simply must be efficient.

${ }^{12}$ See Graham and Krugman 1995.
} 
owned firms relative to that of Japanese-owned firms became stronger (or at least so in the sense that the gap narrowed considerably).

Two points stand out from this example: First, the United States obtained a foreign-owned but domestically located component of the automotive industry that was world class from the outset. Second, the domestic firms that were not world class improved themselves so as to narrow the gap between themselves and the foreign-owned firms. Thus, the benefits of the foreign investment were not that inefficient--domestically owned enterprises were replaced by efficient foreign-owned enterprises. Rather, the United States got, in the end, both efficient foreign-owned enterprises and greatly improved domestically owned enterprises participating in its domestic auto industry.

This was not costless, however. In particular, the domestic firms were forced to shed much redundant labor that, along with obsolete technology, was at the heart of their inefficiency. For a time, there was great fear that the shed labor would become permanently unemployed or underemployed. However, with the economic boom of the 1990s creating a huge supply of new jobs, a boom that was at least partly enabled by the industrial restructuring that took place during the 1980s, few workers that were displaced by the restructuring remain unemployed or even underemployed.

Will foreign invested enterprises in China that exist primarily to serve the domestic market fall into the first possibility or the second? That is, will these firms serve to help create sectors that are internationally competitive (and thus create new comparative advantage for China), or will these sectors become noncompetitive national enclaves? This is an issue that empirical evidence does not seem, at this time at any rate, to resolve. Which of the two outcomes actually transpires, however, depends in great measure on government policy, and this is the subject of the concluding section. But, prior to moving to this, we first present our own empirical findings, ones that we believe solidify the findings of D-G\&H.

\section{ARE THERE TOTAL FACTOR PRODUCTIVITY GROWTH RATE DIFFERENCES ACROSS CHINESE PROVINCES AND DID THESE RATES CHANGE IN THE COASTAL PROVINCES FOLLOWING 1991?}

As noted in the discussion of the D-G\&H results above, probably the most compelling explanation of why FDI in the coastal provinces might have raised per capita growth there, such that this growth outstripped that of other regions of China during the 1990s, was that FDI enabled an acceleration of TFP growth in these provinces not realized elsewhere in China. In this section we thus present efforts to test whether (1) TFP growth in the coastal provinces (and other regions receiving FDI) accelerated following the liberalization enabling FDI to flow to these provinces in large quantities and (2) whether TFP growth in the regions receiving FDI was significantly different than in other regions during the 1990s. 
The results reported here are based on rather simple techniques and should be seen as work in progress rather than as final results. The authors intend in the future to attempt to refine these results using powerful vector autoregressive (VAR) techniques.

TFP is not a variable that can be directly observed but rather must be inferred from other variables. For example, if output is written as a function of inputs of capital and labor using a CobbDouglas specification

$$
Y_{t}=A_{t} K_{t}^{\alpha} L_{t}^{\beta}
$$

the $A_{t}$ term can be interpreted as TFP, where the subscript $t$ is used simply to indicate that this is a quantity that changes over time. In an economic growth model where technological changes is considered to drive TFP and where this change is exogenous (i.e., it just happens), a standard assumption is that $\mathrm{A}_{\mathrm{t}}$ increases over time at some exponential rate

$$
A_{t}=A_{0} e^{r t}
$$

where $\mathrm{A}_{0}$ is simply TFP at $\mathrm{t}=0$. In principle, then, the growth rate of TFP, $r$, can be estimated using ordinary least square regressions by taking logarithms of the expression for $\mathrm{Y}_{\mathrm{t}}$ above:

$$
\log Y_{t}=r t+\alpha \log K_{t}+\beta \log L_{t}+\varepsilon_{t}
$$

where a new independent variable $t$ (which is just time) must be introduced and it must be assumed that errors in $\mathrm{Y}_{\mathrm{t}}$ are independent and identically lognormally distributed.

Even so, observation of TFP is problematic, for the reason that over time the observable independent variables $\mathrm{K}_{t}$ and $\mathrm{L}_{\mathrm{t}}$ tend in most economies to grow following an exponential process and hence are collinear with At (and with each other). To remove collinearity, we first-differenced the variables to yield

$$
\log Y_{t}-\log Y_{t-1}=\log \left(\frac{Y_{t}}{Y_{t-1}}\right)=r+\alpha\left(\log K_{t}-\log K_{t-1}\right)+\beta\left(\log L_{t}-\log L_{t-1}\right)+\varepsilon_{t}-\varepsilon_{t-1}
$$


To this, we added another term $\rho t$, which indicates trend in the series. Note that because the series is already first-differenced, the time trend term picks up second differences. This we interpret as indicating whether the rate of TFP accelerates (if $\rho$ is positive) or decelerates (if $\rho$ is negative) over the relevant time period. (In effect, $\rho$ controls for any trend in the first differences of TFP or other independent variables.) The full specification then is

$$
\log Y_{t}-\log Y_{t-1}=r+\rho t+\alpha\left(\log K_{t}-\log K_{t-1}\right)+\beta\left(\log L_{t}-\log L_{t-1}\right)+\varepsilon_{t}-\varepsilon_{t-1} .
$$

Data used to calculate the values of the parameters $r, \rho, \alpha$, and $\beta$ were as follows: first, because we could not find data on hours worked in China by province or even numbers of persons in the labor force, we substituted population by province, taken from various issues of China Statistical Yearbook. Likewise, we could not find a sufficiently long series on capital stock for our purposes, and hence we calculated a series from data on domestic productive investment (also from China Statistical Yearbook) assuming a 10-year useful life of new capital stock, depreciated on a straight-line basis. All economic flow variables were converted into constant value figures using GDP deflators.

Income by province were provided to us by Dr. Aasim M. Husain of the International Monetary Fund and coauthor of D-G\&H; thus, our income data were exactly the same as those of D-G\&H. We then used ordinary least squares regression to calculate the relevant parameters for six regions of China, using the same regional groupings as D-G\&H. The parameters were calculated for the years 1978-90, 1978-97, and 1991-97. Table 4 indicates the average value of the stock of FDI in each of the six regions as a percent of the total stock of FDI in China over the years 1985-97. Which provinces were in which regional groupings is indicated in table 5 .

What we would expect to find is, if FDI drives higher per capita income growth via an acceleration of TFP growth in the provinces in which FDI is concentrated, then (1) TFP growth in the FDI-intensive areas (mostly the coastal region but possibly also the northern and northeast regions) is significantly greater than in other areas during the 1991-97 period but not during the 1978-90 period ${ }^{13}$; and (2) TFP in the coastal areas is significantly higher in the FDI-intensive areas in the 1991-97 period than in the earlier period.

\footnotetext{
${ }^{13}$ Although, as noted in the previous section, reforms enabling greater FDI in China were implemented in 1992, we find that the 1990s "wave" of FDI flow into China began in 1991.
} 
The relevant results are presented in table 5. The overall findings are in fact consistent with our expectations, but a number of unresolved issues are also revealed in these finds.

Table 4 Share of foreign direct investment in China, by region

\begin{tabular}{ll}
\hline Region & Share of FDI (percent) \\
\hline Northern & 11.02 \\
Northeastern & 6.42 \\
Coastal & 71.28 \\
Southeastern & 4.76 \\
Southern & 4.54 \\
Western & 1.98 \\
\hline
\end{tabular}

Note: Figures are average for 1985-97.

Source: Calculated from data in China Statistical Yearbook. 
Table 5 Estimated parameters for Cobb-Douglas production function, by region and time period Dependent variable: Real GDP ${ }^{\mathrm{a}}$

\begin{tabular}{lll}
\hline Region & $1978-90$ & $1991-97$
\end{tabular}

Coastal region (Shanghai, Jiangsu, Zhejiang, Fujian, Shandong, Guangdong, and Hainan)

Independent variables

Population $^{\mathrm{b}}$

Capital stock

Time trend

Constant (TFP growth rate)

R-squared
OLS coefficients

$\begin{array}{rlrl}-0.24 & & 4.40 & * * \\ 1.02 & * * & 0.51 & * * \\ -0.01 & * * & -0.01 & * * \\ 0.03 & 0.26 & * *\end{array}$

0.65

0.99

Northern region (Geijing, Tianjin, Hebei, Shangzi, and Inner Mongolia)

Independent variables

Population $^{\mathrm{b}}$

Capital stock ${ }^{\mathrm{c}}$

Time trend

Constant (TFP growth rate)

R-squared

Northeastern region (Liaoning, Jilin, and Heilongjiang)

Independent variables

Population $^{b}$

Capital stock ${ }^{\mathrm{c}}$

Time trend

Constant (TFP growth rate)

R-squared
OLS coefficients

$\begin{array}{rrr}3.63 & 0.01 & \\ 0.99 * * & 0.33 & \\ -0.01 & -0.01 & * * \\ 0.00 & 0.18 & * *\end{array}$

0.46

0.90

\begin{tabular}{lcc}
\hline Population $^{\mathrm{b}}$ & 2.99 & -3.27 \\
${ } \mathrm{c}^{\mathrm{c}} }$ & $1.03 * *$ & 0.31 \\
Time trend & -0.01 & -0.00 \\
Constant (TFP growth rate) & 0.01 & 0.10 \\
& & \\
R-squared & 0.54 & 0.64
\end{tabular}


Table 5 (continued)

Southeastern region (Anhui, Jiangxi, Henan, Hubei, and Hunan)

Independent variables

Population $^{\mathrm{b}}$

Capital stock ${ }^{\mathrm{c}}$

Time trend

Constant (TFP growth rate)

R-squared

\section{OLS coefficients}

$\begin{array}{rrr}-7.45 & -0.32 & \\ 0.29 & 0.74 & \text { * } \\ -0.00 & -0.01 & \text { ** } \\ 0.18 & * & 0.19\end{array}$ **

0.72

0.93

Southern region (Guangzi, Sichuan, Guizhou, and Yunnan)

Independent variables

Population $^{\text {b }}$

Capital stock ${ }^{\mathrm{c}}$

Time trend

Constant (TFP growth rate)

R-squared

\section{OLS coefficients}

$\begin{array}{rrrr}-6.29 & & -0.21 & \\ 0.81 & * & 0.55 & * \\ -0.00 & -0.01 & * \\ 0.12 & * & 0.14 & *\end{array}$

0.53

Western region (Tibet, Shaanxi, Gansu, Qinghai, Ningxia, and Xinjian)

Independent variables

Population $^{\mathrm{b}}$

Capital stock ${ }^{\mathrm{c}}$

Time trend

Constant (TFP growth rate)
OLS coefficients

$\begin{array}{rrr}3.14 & * & -1.68 \\ 1.43 & * * & 0.04 \\ -0.01 & & -0.00 \\ -0.02 & & 0.19\end{array}$

0.57

0.44

Notes: a. Variables are first-difference of log of real GDP.

b. Variables are first-difference of log of population.

c. Variables are first-difference of log of capital stock.

* indicates coefficients are significant at 90 percent level of confidence.

** indicates coefficients are significant at 95 percent level of confidence.

OLS $=$ ordinary least squares

TFP $=$ total factor productivity

Source: Authors' calculations. Data sources for base data are described in main text. 
In particular, consistent with expectations, rates of increase of TFP (recall that this is captured in the constant term) do jump in the 1991-97 time period over the 1978-90 period in the region most affected by FDI, the coastal region, and less spectacularly in the northern region. In both these regions, in fact, the rate of TFP growth, while measured as positive, was not significantly different than zero in the earlier period, while in the later period in both cases it was positive and significant. The rate of growth of TFP in the coastal region was the greatest, as we would expect. TFP growth in the northeastern region also increased in the second time period, but this result is not statistically significant. We find that in the coastal region the rate of TFP increase did decelerate somewhat during the 1991-97 period and that this was significant but slow. This might be interpreted as consistent with a hypothesis that western and Japanese firms are contributing less to TFP growth than export-oriented Asian source FDI.

Was the rate of TFP increase significantly different in the coastal regions from that in other areas in the 1991-97 period but not the 1978-90 period? Table 6 presents results based on F-tests. What we find is that the differences that seem so clear in Table 5 are in fact generally not significantly different from one another. This result seems to us anomalous and indeed could be an artifact of the F-test. What the Ftest is telling us is, in effect, that because the number of observations in each time period is small (indeed, we have only seven observations for the critical post-1990 time period), we cannot be too confident of the results.

\section{Table 6 Does TFP growth differ in noncoastal regions of China from the coastal region?}

\begin{tabular}{rcc}
\hline Region & $\mathbf{1 9 7 8 - 9 0}$ & $\mathbf{1 9 9 0 - 9 7}$ \\
\cline { 2 - 3 } Northern & No & No \\
Northeastern & No & No \\
Southeastern & Yes & No \\
Southern & No & Yes \\
Western & No & No \\
\hline
\end{tabular}

Note: Results are based on F-test at 90 percent level of confidence using regression results reported in table 5. 
Other problems are revealed in the results. For each of the sets of results reported in table 5, the coefficients for labor and capital should sum to one, or at least so if we assume constant returns to scale, as is an appropriate assumption for aggregated income data. However, the reported coefficients obviously do not sum to unity. In fact, however, the results are not quite as bad as they would seem, because a t-test indicates that in most instances these sums are not statistically significantly different than unity and hence the hypothesis that they do sum to unity cannot be rejected. Somewhat more problematic are the negative coefficients that appear on labor for some of the results, an unlikely result. Again, these coefficients are not significantly different from zero, so the hypothesis that they are in fact negative can be rejected; but, unfortunately, so can the hypothesis that they are positive. We conjecture that a distortion is introduced into the results because we were forced by data limitations to use population rather than hours worked or some other better measure of labor input. Because of China's zero-population growth policies, it is plausible that population grew more slowly over the time period covered by the analysis than labor input (possibly due to rising participation of females in the labor force). Also, official figures on population in China do not fully account for internal migration that has occurred there, because persons may be listed by province of birth rather than province of actual current residence. (This is because internal migration in China nominally requires state permission, but many persons circumvent state controls on this migration simply by failing to report their current residence.) Finally, the same problem as reported by Mankiw et al., notably that the capital share of income implied by the coefficients on capital is implausibly high, appears in our results. This, as shown by Mankiw et al., might be correctable by inclusion of a variable to indicate human capital but, again, we simply do not have the data needed to do so.

These problems notwithstanding, we conclude that our results at least crudely support the findings of D-G\&H, notably that FDI has contributed to growth in relevant regions of China beyond that which would be expected from higher rates of capital formation enabled by the FDI. In particular, we tentatively conclude that TFP growth did accelerate in the coastal region of China, where the bulk of FDI has taken place since 1991, relative to other regions of China. Likewise, there is weaker evidence of some relative acceleration of TFP growth in the northern region, which also received significant amounts of FDI. But, because the northern region lagged far behind the coastal region, we find, as might be expected, that TFP growth in the former considerably lagged the growth in the latter.

\section{DOES CHINESE POLICY TOWARDS FOREIGN DIRECT INVESTMENT NEED TO CHANGE?}

To answer this question, one really needs first to answer the question "Is China receiving close to the maximum potential benefit from existing FDI"? A central problem is, of course, we really do not know the answer to this question. The D-G\&H results, as buttressed by our own results, in fact suggest that 
China might receive more benefit than expected (at least by some commentators) from FDI that is concentrated in export-processing activities that still constitute the majority of foreign-invested operations in China. But these results do not differentiate among this type of FDI and import-substituting FDI. The latter, as argued earlier, is generated by western and Japanese multinational firms who invest in sectors in which China does not have a revealed comparative advantage. This, however, does not suggest that China will never have comparative advantage in these sectors. Indeed, at issue is whether this investment is creating efficiencies that might ultimately transform these sectors into ones in which China will have future comparative advantage. Importantly, this investment also has the potential to transform existing enterprises in China, including the state-owned ones, towards levels of world-class efficiency.

The sense that one has is, alas, that neither of these transformations is happening as quickly as it could. Rather, foreign investors operating in import substitution sectors face a host of obstacles that ultimately impede modernization of the Chinese economy and the clearance of which requires in some cases quite fundamental reforms. A common litany of these obstacles is that (1) property rights need to be better defined in China, including those established by contractual relationships; (2) the judiciary in China needs to be reformed so as to enhance its independence, impartiality, fairness, and incorruptability; and (3) the government (including at local and regional as well as national levels) should remove itself from interfering with commercial decisions, for example, specifying to foreign-invested enterprises with which suppliers these enterprises should associate themselves.

However, as suggested in the introduction to this paper, we believe that the change most needed in China is one that goes beyond this common litany. Notably, what is needed is an overhaul of Chinese revealed preferences towards competition. With respect to competition, in a word, China needs more of it.

How to achieve this? Certainly, one way is to reduce or remove barriers to entry and obstacles to efficiency that seem to plague many if not most foreign-invested enterprises that operate in sectors where they must compete with domestic rivals. In the current context, the latter - that is, barriers to achievement of maximum efficiency - might often be more important than entry barriers per se. Thus, for example, a large western firm seeking to make a major investment in China rarely finds that it is forbidden from doing so, but often finds that many conditions accompany permission to invest that tend to reduce, rather than enhance, the efficiency of the undertaking. Some of these indeed fall on the list of the "common litany" listed just above, for example, requirements that the undertaking utilize local suppliers that are specified by the government. But some of these fall into the domain of restrictions that would be considered in many nations to be anticompetitive, were they not the product of sovereign compulsion, for example, restrictions on territory in which product can be marketed, restrictions on the scope of products that can be produced, and restrictions on prices that can be charged. Indeed, to listen to anecdotes as told 
by western and Japanese executives with experience in China, often they are in effect required to participate in what amount to state-sponsored cartels.

The ending of these practices would, of course, often expose state-owned enterprises to potentially crushing competition and, presumably, this is the main reason for the restrictions. In a word, the authorities seek to prevent this from happening. However, this creates a major quandary: the reason why the state-owned enterprises are vulnerable is that they are inefficient and noncompetitive, but the more that they are protected from potentially crushing competition, the less incentive they have to take those steps necessary to improve their competitiveness. ${ }^{14}$

Thus, what would seem to be called for in China is what might be termed a program of procompetitive deregulation whereby conditions and limitations placed upon foreign-invested enterprises that are anticompetitive in effect are dismantled and, where appropriate, replaced by more procompetitive measures. Such a phase-out might be gradual, in order to give state-owned enterprises (and, indeed, foreign-invested enterprises as well) time to adjust. However, the phase-out should be pre-announced, so that a schedule of specific steps that will be taken is published and adhered to.

Competition is a two-edged sword and, if implemented, the phase-out described just above would create significant adjustment costs for some foreign-invested enterprises as well as domestically owned ones. Thus, for example, it is widely reported that major automotive (and bus and truck) operations that have been established in China under foreign ownership are subject to numerous conditions whose effects are anticompetitive and, likely, efficiency-diminishing. Offsetting these to some extent from the investors' points of view, the authorities have implemented measures to grant to these operations some protection from competition by imports or by entry by rival foreign firms. The incumbent foreigninvested enterprises might welcome the dismantling of the former but not necessarily the latter and, indeed, might cry "contract violation" if the protective measures are withdrawn. But procompetitive deregulation does indeed require the removal of the latter as well as the former. And, with respect to this, China might want to take note of the largely negative examples of certain other developing countries that have attempted to foster internal industrial development by implementing policies to allow foreign firms to participate in specific sectors under tight regulation but that also simultaneously protects these firms from competition from other foreign firms. The result typically has been that the foreign-controlled sector, while more efficient than its domestically owned counterpart, is nonetheless noncompetitive internationally. For examples, see Moran 1998. The consequence of such polic ies, as one example, can be

\footnotetext{
${ }^{14}$ The reader will note that the word "competitive" is, in these paragraphs, being used in two somewhat different senses: first, to denote the fostering of more competition (e.g, "the government adopted a more procompetitive policy"); and, second, to denote the attainment of efficiencies and other qualities on the part of an enterprise necessary to compete effectively (e.g., "the firm took measures to make itself more competitive").
} 
found in Mexico. Because of inefficiencies that such policies had created in the auto sector, Mexico found itself under pressure not to grant full and unconditional access to its auto market to new foreign entrants under the North American Free Trade Agreement (NAFTA). Rather, new entrants into this sector in Mexico must face restrictions similar to those imposed on incumbent foreign-controlled firms (Hufbauer and Schott 1996). These restrictions will be phased out over time but, in the interim, auto production in Mexico is partially exempt from market opening under NAFTA. It is arguably Mexico itself who loses benefit.

An additional step that China should implement is to allow foreign takeover of incumbent stateowned enterprises on terms that foreign investors can accept. Often, such takeover enables improvement in the operations of the acquired enterprise needed to make it competitive. China, to be sure, does not specifically forbid such takeover. Indeed, during a recent visit to Beijing, one of the authors (Graham) was reassured by a senior official of the Ministry of Foreign Trade and Economic Cooperation (MOFTEC) that such foreign takeover was welcome, provided that the investor honor the implicit and explicit contracts that exist between the enterprise and its employees. However, the implicit contract is that not only will present levels of employment be maintained, but also there will be provided what amounts to cradle-to-grave social assurance for all employees plus of course their families. Given that it can be exactly these obligations that make the enterprise noncompetitive to begin with, it is clear that the effect of requiring foreign investors to take on this contract is to deter foreign takeover if not effectively to block it altogether. Indeed, foreign takeover only makes sense if the foreign investor is allowed to implement measures to make the enterprise competitive and, alas, for most state-owned enterprises in China, this typically will require labor shedding.

This leaves us with a rather great quandary, one on which this paper will close. This is that the Chinese government rightly worries about the growing disparities in per capita income between the fastgrowing, FDI-fueled coastal provinces and the sluggish interior provinces. At the extreme, these disparities could lead to social tensions that could disrupt the generally harmonious character of Chinese society and perhaps even lead to a breakdown of the social order, as has happened in the last with disastrous consequences in the long history of China. On the other hand, in the name of preserving employment, the Chinese government pursues policies that arguably reinforce the already extant locational advantages held by coastal provinces with respect to foreign investment. Foreign investment in the interior, in particular, is likely, if it is to happen at all, to be characterized more by takeover of existing enterprises and less by greenfield investment than in the coastal areas. But, as just noted, such takeover is effectively blocked and, indeed, policies are maintained that create inefficiencies in those foreign-invested enterprises that compete with incumbent domestic firms. 
Thus, the quandary is that present policy actually reinforces regional disparities that could be destabilizing by attempting to preserve the current industrial structure in the interior provinces. But, if this structure is disrupted, this could also prove to be destabilizing. Thus, to prevent social instability, the government pursues policies that themselves are increasingly destabilizing. How to break the quandary is vexing, but we would suggest that a phase-in of procompetitive deregulation offers the best hope. The main problem is that such a phase-in would force adjustments not only in domestic Chinese enterprises but also in incumbent foreign-controlled ones, and hence resistance would be very high.

What should be done then? Well, one fall-back that has been used to good effect in China's past is to continue to make the reforms necessary to modernize but to blame the costs of these on foreigners. But which foreigner? The obvious candidate is the WTO! The phase-in of procompetitive deregulation in fact could be accomplished largely in the guise of requirements to meet WTO obligations. China for so long patiently sought WTO membership largely on grounds that this membership would bring benefits to China, but not without some pain. Chinese leaders have in fact already created an expectation of some pain associated with WTO accession. Now that this accession is close at hand, the time has come for these leaders to ask China to take the bitter medicine that comes with WTO membership while assuring the Chinese people of what the truth is, that the medicine is good even if it tastes rather bad. 


\section{APPENDIX: \\ THE MANKIW-ROMER-WEILL VERSION OF THE SOLOW GROWTH MODEL}

In Robert Solow's model of economic growth (Solow 1956), diminishing returns to capital imply a convergence of the capitalto-labor ratio to a value such that, once this value is reached, further growth in per capita income cannot be accomplished via further capital deepening. Per capita income growth can still be accomplished by increases in total factor productivity, of course, but for analytic convenience the growth of TFP is assumed to be exogenously determined and to increase at a constant rate (i.e. if $A_{t}$ is TFP at time $t$, it is assumed to evolve according to $A_{t}=A_{0} e^{n t}$, where $n$ and $A_{0}$ are constants). The steady state ratio is then determined by (1) the rate of growth of the labor force, which is generally also assumed to grow at a constant rate and which, in tests of the model, is inferred from actual growth of the workforce, (2) the rate of savings in the economy (i.e., the percentage of output each year that is converted to capital formation in most versions of the model, which assume closed economies), (3) the rate of increase of TFP, and the rate of depreciation of the capital stock, which is usually assumed to be a constant fraction $\delta$ of the total stock of extant capital.

Specifically, if the stock of capital at time $t$ is $\mathrm{K}_{\mathrm{t}}$, then this stock evolves under the dynamic $\mathrm{dK}_{\mathrm{t}} / \mathrm{dt}=\mathrm{sY}_{\mathrm{t}}-\delta \mathrm{K}_{\mathrm{t}}$ where $\mathrm{Y}_{\mathrm{t}}$ is income at time $\mathrm{t}$ and $\mathrm{s}$ is the fraction of income that is converted to capital. If $\mathrm{Y}_{\mathrm{t}}$ is determined by a Cobb-Douglas production function of form $\mathrm{Y}_{\mathrm{t}}=\mathrm{K}_{\mathrm{t}}{ }^{\alpha}\left(\mathrm{A}_{\mathrm{t}} \mathrm{L}_{\mathrm{t}}\right)^{1-\alpha} \quad(0<\alpha<1)$. If $\mathrm{y}$ and $\mathrm{k}$ indicate income and the stock of capital normalized by the "effective" amount of labor (i.e., and dropping the time subscripts, $\mathrm{y}=\mathrm{Y} / \mathrm{AL}$ and $\mathrm{k}=\mathrm{K} / \mathrm{AL}$ ), then

$$
\mathrm{dk} / \mathrm{dt}=\mathrm{sy}-(\mathrm{n}+\mathrm{g}+\delta) \mathrm{k}=\mathrm{sk}^{\alpha}-(\mathrm{n}+\mathrm{g}+\delta) \mathrm{k}
$$

Solution of this differential equation reveals that, with the passage of time, $\mathrm{dk} / \mathrm{dt} \rightarrow 0$, implying that $\mathrm{sk}^{\alpha}-(\mathrm{n}+\mathrm{g}+\delta) \mathrm{k} \rightarrow 0$ or that $\mathrm{k}$ reaches a steady state value $\mathrm{k}^{*}=[\mathrm{s} /(\mathrm{n}+\mathrm{g}+\delta)]^{1 /(1-\alpha)}$. If the current capital to labor ratio is less than that of steady state ratio, capital deepening will occur, creating growth in per capita income above the steady state rate that will persist until the capital to labor ratio reaches the steady state value, at which point growth will itself reach a steady state path.

Mankiw, Romer, and Weil (1992) test the basic Solow model just described across several samples of countries and find that, contrary to the expectations of a number of economists, the data fit the model quite well. A key matter in this regard is whether, as is sometimes claimed, the model implies that TFP increases at the same rate in all countries. In fact, it is a common misstatement that the model assumes the level of TFP at the beginning of the sample period to be the same across countries, which would be clearly counter-indicated by the evidence: clearly, TFP differences do exist among countries, 
and these persist. What is true is that the original Solow model holds the initial differences constant across countries. In the model, a country that starts, in terms of the level of TFP, behind another country stays behind perpetually. Because, in the model, technology is exogenous, the model does not allow for the possibility that a country might endogenously increase the rate at which its economy produces new technology and thus pull ahead of its rivals. This has led to much criticism of the model, for example., from advocates of endogenous growth theory. However, as Mankiw et al. note, there is nothing in the technical specification of the Solow model to prevent two different countries from converging to two different growth trajectories; this possibility does seem to violate the notion that technological change occurs exogenously. However, this is not a subject that we wish to dwell upon here. The point is that, if one allows countries to converge to different growth paths, the Solow model fits the data quite well.

However, Mankiw et al. do find one major flaw with the Solow model. This is, because it is based on a Cobb-Douglas production function, the coefficient $\alpha$ of capital must be interpreted as the income elasticity of capital. Because this function is linear homogenous, an appeal to Euler's theorem for such functions shows that capital must be paid its marginal product and that $\alpha$ thus is also equal to capital's share of total income. National income accounts show that this share for the developed economies is about 0.35 but, if the value of $\alpha$ is unconstrained in the cross sectional regressions performed by Mankiw et al., the calculated value of this elasticity is close to 0.6. They thus conclude that, because of the implausible value of this coefficient, the Solow model is not sufficient to explain observed cross-country variation in real per capita income growth in spite of the goodness of fit.

They then show that if the model is augmented so as to include human capital, its explanatory power is greatly increased. The augmented production function now becomes as follows, again omitting the time subscripts for $\mathrm{Y}, \mathrm{K}, \mathrm{H}, \mathrm{A}$, and L:

$$
\mathrm{Y}=\mathrm{K}^{\alpha} \mathrm{H}^{\beta}(\mathrm{AL})^{1-\alpha-\beta} \quad(\alpha, \beta>0 ; 0<\alpha+\beta<1)
$$

where $\mathrm{H}$ is now "human capital", essentially investment in education. The dynamics of growth now are governed by two differential equations each similar to that of the Solow model but now depicting simultaneous evolution of human and physical capital:

$$
\begin{aligned}
& \mathrm{dk} / \mathrm{dt}=\mathrm{s}_{\mathrm{k}} \mathrm{y}-(\mathrm{n}+\mathrm{g}+\delta) \mathrm{k} \\
& \mathrm{dh} / \mathrm{dt}=\mathrm{s}_{\mathrm{h}} \mathrm{y}-(\mathrm{n}+\mathrm{g}+\delta) \mathrm{h}
\end{aligned}
$$


where, once again, lower case letters indicate the variable per effective unit of labor (e.g., $h=H / A L)$, and time subscripts have been omitted but are implicit. The coefficients $s_{k}$ and $s_{h}$ indicate the fractions of current income that are invested in physical and human capital respectively. Implicit in these equations is that human and physical capital should depreciate at the same rate $\delta$. This is not explained, nor indeed is it explained why human capital should depreciate at all. ${ }^{15}$

The two differential equations imply convergence of both $\mathrm{dk} / \mathrm{dt}$ and $\mathrm{dh} / \mathrm{dt}$ to zero, implying convergence of $\mathrm{k}$ and $\mathrm{h}$ to equilibrium values $\mathrm{k}^{*}$ and $\mathrm{h} *$ given by

$$
\begin{aligned}
& \mathrm{k}^{*}=\left[\mathrm{s}_{\mathrm{k}}{ }^{1-\beta} \mathrm{s}_{\mathrm{h}}{ }^{\beta} /(\mathrm{n}+\mathrm{g}+\delta)\right]^{1 /(1-\alpha-\beta)} \\
& \mathrm{h}^{*}=\left[\mathrm{s}_{\mathrm{k}}{ }^{\alpha} \mathrm{s}_{\mathrm{h}}{ }^{1-\alpha} /(\mathrm{n}+\mathrm{g}+\delta)\right]^{1 /(1-\alpha-\beta)}
\end{aligned}
$$

This convergence implies that

$$
\ln \left(\mathrm{Y}_{\mathrm{t}} / \mathrm{L}_{\mathrm{t}}\right)=\ln \mathrm{A}_{0}+\mathrm{gt}+[\alpha /(1-\alpha)] \ln \mathrm{s}_{\mathrm{k}}-[\alpha /(1-\alpha)] \ln (\mathrm{n}+\mathrm{g}+\delta)+[\beta /(1-\alpha)] \ln \mathrm{h}^{*} .
$$

Thus, in this formulation, income per worker at time $\mathrm{t}$ (note: this time around, not "effective worker") depends positively on initial total factor productivity $\mathrm{A}_{0}$, growth rate of TFP $\mathrm{g}$, the proportion of output converted to capital (the savings rate), and equilibrium human capital per person. This income depends negatively on the sum of population growth rate, TFP growth rate, and the rate of depreciation. Mankiw et al. show that such a model, when empirically tested, seems to explain real per capita income growth variation across nations, especially the high-income OECD nations, quite well and, furthermore, yields a value of $\alpha$ that is consistent with income share of capital. They go on to show that convergence to the equilibrium is much slower in this model than in the original Solow model (the typical "half life" the time that it would take a typical economy to close the gap between current growth of per capita income and the equilibrium - is 35 years, more than twice that predicted by the unaugmented Solow model). The model does not predict that countries all converge to the same equilibrium, but only that each country will reach a steady state determined only by accumulation of physical and human capital and population growth. The convergence is given (approximately) by $\ln y_{t}=\left(1-e^{-\lambda t}\right) \ln y^{*}+e^{-\lambda t} \ln y_{0}$ where $\lambda$ is the rate of convergence, $\lambda=(n+g+\delta) /(1-\alpha-\beta)$. Substituting for $y^{*}$ and subtracting $\ln y_{0}$ from both sides of the equation, this last expression, on which the D-G\&H analysis rests, becomes

\footnotetext{
${ }^{15}$ Mankiw et al. offer only the explanation "we believe ... it is natural to assume that the two types of production functions (i.e., those for physical and human capital) are similar", which is in this author's view tantamount to no explanation at all.
} 
$\ln y_{t}-\ln y_{0}=\left[\left(1-e^{-\lambda t}\right)\right]\left[\alpha \ln s_{k}+\beta \ln s_{h}-(\alpha+\beta) \ln (n+g+\delta)\right]-\left(1-e^{-\lambda t}\right) \ln y_{0}$.

This is the relationship on which empirical estimates of the determinants of growth using the Mankiw, Romer, and Weil model rest. 


\section{REFERENCES}

Dayal-Gulati, Anuradha. and Aasim M. Husain. 2000. Centripetal Forces in China's Economic Take-off. IMF Working Paper WP/00/86. Washington: International Monetary Fund.

Graham, Edward and Paul R. Krugman. 1995. Foreign Direct investment in the United States, $3^{\text {rd }}$ ed. Washington: Institute for International Economics.

Hufbauer, Gary C. and Jeffrey J. Schott. 1992. North American Free Trade: Issues and Recommendations. Washington: Institute for International Economics.

Lardy, Nicholas. 1998. China's Unfinished Economic Revolution. Washington: The Brookings Institution.

Lemoine, Francoise. 2000. FDI and Opening up the Chinese Economy. CEPII Working Paper 2000-11, Paris: Centre d'Etudes Prospectives et d'Information Internationale.

Mankiw, N.G., David Romer, and David Weil. 1992. "A Contribution to the Empirics of Economic Growth”. Quarterly Journal of Economics, 107, 2(May), 407-437.

Moran, T.H. 1998. Foreign Direct Investment and Development. Washington: Institute for International Economics.

Rosen, Daniel H. 1999. Behind the Open Door - Foreign Enterprises in the Chinese Marketplace. Washington: Institute for International Economics.

Solow, Robert M. 1956. "A Contribution to the Theory of Economic Growth". Quarterly Journal of Economics, Vol. 70, pp. 65-94.

Wei, Shang Jin. 1995. "The Open Door Policy and the China's Rapid Growth: Evidence from City-Level Data," in Takatoshi Ito and Anne Krueger, editors, Growth Theories in Light of the East Asian Experience. Chicago: University of Chicago Press.

Wei, Shang Jin. 1996. "Foreign Direct Investment in China: Sources and Consequences," in Takatoshi Ito and Anne Krueger, editors, Financial Deregulation and Integration in East Asia. Chicago: University of Chicago Press. 